\title{
Ethics-Related Issues in the Tender Evaluation of Malaysia Public Projects
}

\author{
Fadzida Ismail ${ }^{1}$, Mohd Suhaimi Mohd Danuri2*, Othman Mohamed ${ }^{3}$, Saipol Bari \\ Abdul-Karim ${ }^{4}$ and Mohd Nasrun Mohd Nawi ${ }^{5}$ \\ ${ }^{1,2,3,4}$ Centre for Building, Construction \& Tropical Architecture (BuCTA), Faculty of Built \\ Environment, University of Malaya, Kuala Lumpur, \\ ${ }^{5}$ School of Technology Management and Logistic, Universiti Utara Malaysia \\ 2*msuhaimi@um.edu.my
}

\begin{abstract}
Ethical practice is usually addressed in the forms of code of conduct, rules and regulations, agreement, and contract. There is a lack of empirical studies on ethical issues involving contractors during tender application submission. Therefore, to begin with, a preliminary research was conducted in an attempt to explore the presence of ethical issues at tendering stage, particularly at the beginning of the tender evaluation stage. The research methodology was qualitative as telephone interviews were used for its data collection method. The participants were selected from a purposive sampling consisting of local authorities and other agencies. Seventy-five percent of the participants claimed of having come across unethical cases. Surprisingly, the findings showed that falsifications of documents by the tenderers were identified during the tender application submission stage. It was also found that the lower grade contractors are prone to practise unethically compared to the higher-grade counterparts. The industry should seriously address these findings as it could possibly reduce the competitiveness of tenders and affect the overall project performance. This research is crucial in order to suggest the way forward for tendering practice, instil the ethical practice of the contractors, assist tender evaluators, and most importantly, elevate the study in refining the tender submission process.
\end{abstract}

Keywords: Ethics, Contractor, Construction, Tender, Quotation

\section{INTRODUCTION}

Construction industry is not only seen as physically challenging, dirty, and dangerous (Ling, Leow, \& Lee, 2016), but also discouraging people from the industry. Nevertheless, it is needed for the nation development as it contributes to the economy of the country. The codes of ethics are being introduced to guard and guide the practice of the practitioners and professionals. The view of other countries however regards professional ethics as a sensitive subject. Even though the codes of ethics are established to ensure quality and avoid conflicts of interests, unethical behaviours can still be detected from the decisions made at the top management level just for the sake to close the deal and out of greed (Lindebaum, Geddes, \& Gabriel, 2017; Nordin, Takim, \& Nawawi, 2013; Raja, 2014; Scalza, 2008). In view of overcoming this issue, suspension of practising licence is foreseen as a punishment. For instance, in Malaysia, contractors face the possibility of their licence being suspended by the relevant authority body for unethical behaviours (Yahya, 2016).

The issues of integrity and ethics have been long debated. The seriousness of the issues captured the attention of the nation, hence the incorporation of them in the Construction Industry Master Plan (CIMP) 2010-2015. Not only in a thrust, but in two thrusts, i.e., 'strengthen the construction industry image' and 'strive for the highest standard of quality'. Continuing the CIMP is the Construction Industry Transformation Programme (CITP) 2016-2020, which is currently in use, 'addressing quality and professionalism' in one of its four thrusts.

This paper explored the issues of integrity and ethics among Malaysian contractors during tender application submission. Specifically, thispaper presented whether unethical issues appeared during tendering, established the classification of the contractor registration grades who are usually involved in unethical issues, and identified the actions taken by the 
local authorities and agencies in the event of an unethical occurrence.

\section{LITERATURE REVIEW}

One reason for arising issues on ethics is different perception and goals. A study by Park and Lee (2014) supported that perceived similarity influences trust. Jaafar and Nuruddin (2012) proposed for a more rigorous research done on the procurement systems in Malaysia which impact poor project performance. First, this research looked into the process in the procurement system and compared it with the practice of other countries. Then, this research narrowed down and focused at the starting point of the procurement process where the contractors involved become the project team member by submitting their tender application for evaluation. The appearance of ethical issues is probed at the stage of tender evaluation.

\subsection{Phases of Construction}

Every project is unique, but the process of any construction project will undergo the phases as illustrated in the Guide to the Project Management Body of Knowledge (Project Management Institute, 2013) in figure 15.

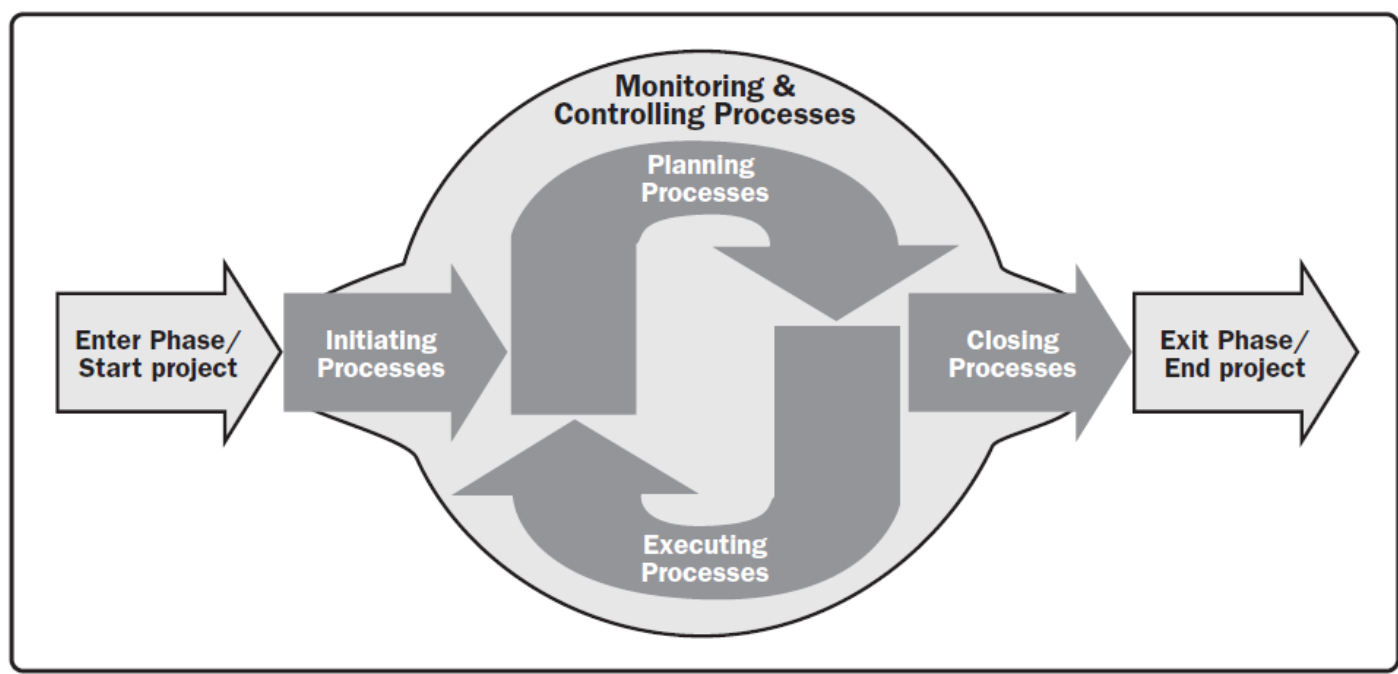

Figure 1: The Project Management Process Groups

Source: Project Management Institute (2013)

The tendering process is one of the initiating processes. In relation to the public projects in Malaysia, the procedure is managed by the Ministry of Finance (MOF). Generally, the Malaysian tendering practice is similar to the international tendering practice, involving all the processes in the project management process group as in Figure 15.

The comparison of Malaysian and other international tendering practices is shown in Table 1.

Table 1: The Practice of Tendering Process in Malaysia and Other Countries

\begin{tabular}{|c|c|c|c|c|}
\hline $\begin{array}{l}\text { Tendering } \\
\text { process }\end{array}$ & $\begin{array}{l}\text { Malaysia } \\
\text { Source: Kaedah } \\
\text { Perolehan } \\
\text { Kerajaan } \\
\text { (Government } \\
\text { Procurement } \\
\text { Methods), } \\
\text { Ministry of } \\
\text { Finance Malaysia } \\
\text { (MOF, 2015) }\end{array}$ & $\begin{array}{l}\text { United Kingdom } \\
\text { and Ireland } \\
\text { Source: Enterprise } \\
\text { Ireland (2004) and } \\
\text { CMS Law-Now } \\
(2015)\end{array}$ & $\begin{array}{l}\text { Australia } \\
\text { Source: Evans \& } \\
\text { Peck Pty Limited } \\
\text { \& Australian } \\
\text { Constructors } \\
\text { Association (2006) } \\
\text { and Department } \\
\text { of Finance and } \\
\text { Deregulation } \\
(2013)\end{array}$ & $\begin{array}{l}\text { New Zealand } \\
\text { Source: Controller } \\
\text { and Auditor- } \\
\text { General (2008) }\end{array}$ \\
\hline $\begin{array}{l}\text { Tender } \\
\text { preparation }\end{array}$ & $\begin{array}{l}\text { Determine project } \\
\text { type and scope of } \\
\text { work }\end{array}$ & $\begin{array}{l}\text { Budget } \\
\text { Document } \\
\text { preparation }\end{array}$ & $\begin{array}{l}\text { Project definition } \\
\text { and scoping } \\
\text { Selection process }\end{array}$ & $\begin{array}{l}\text { Preparing the } \\
\text { tender or proposal } \\
\text { package }\end{array}$ \\
\hline
\end{tabular}




\begin{tabular}{|c|c|c|c|c|}
\hline & $\begin{array}{l}\text { Determine the type } \\
\text { of tender } \\
\text { Tender document } \\
\text { preparation }\end{array}$ & & $\begin{array}{l}\text { for tenderers } \\
\text { Tender } \\
\text { documentation } \\
\text { Criteria for } \\
\text { selection }\end{array}$ & \\
\hline $\begin{array}{l}\text { Call for } \\
\text { tender }\end{array}$ & $\begin{array}{l}\text { - Tender } \\
\text { advertisement } \\
\text { - Tender closing }\end{array}$ & $\begin{array}{l}\text { - Advertisement } \\
\text { - Candidate selection } \\
\text { - Bid preparation }\end{array}$ & $\begin{array}{l}\text { - Call for tenders } \\
\text { - Responding to } \\
\text { invitations to tender } \\
\& \text { developing the } \\
\text { commercial offer } \\
\text { - Tender meetings \& } \\
\text { enquiries } \\
\text { - Amendments to } \\
\text { tender documents } \\
\text { - Submission \& } \\
\text { closing of tenders }\end{array}$ & $\begin{array}{l}\text { - Advertising } \\
\text { - Distribution of the } \\
\text { tender or proposal } \\
\text { package } \\
\text { - Participant briefings } \\
\text { - Managing requests } \\
\text { for additional } \\
\text { information } \\
\text { - Receipt of tenders } \\
\text { or proposals }\end{array}$ \\
\hline $\begin{array}{l}\text { Tender } \\
\text { evaluation }\end{array}$ & $\begin{array}{l}\text { - Technical \& } \\
\text { financial evaluation } \\
\text { - Prepare tender } \\
\text { briefing document } \\
\text { - Present tender } \\
\text { briefing document } \\
\text { to Agency } \\
\text { Procurement Board } \\
\text { - Release letter of } \\
\text { intent } \\
\text { - Conduct negotiation } \\
\text { and reach } \\
\text { agreement }\end{array}$ & - Evaluate bids & $\begin{array}{l}\text { - Tender analysis } \\
\text { - Tender } \\
\text { clarifications }\end{array}$ & $\begin{array}{l}\text { - Evaluation } \\
\text { - Participant } \\
\text { presentations } \\
\text { - Clarification during } \\
\text { the evaluation } \\
\text { process }\end{array}$ \\
\hline $\begin{array}{l}\text { Tender } \\
\text { conclusion }\end{array}$ & $\begin{array}{l}\text { - Release letter of } \\
\text { acceptance } \\
\text { - Contract signing }\end{array}$ & - Award contract & $\begin{array}{l}\text { - Final contract } \\
\text { negotiations } \\
\text { - Tender selection \& } \\
\text { award }\end{array}$ & $\begin{array}{l}\text { - Awarding } \\
\text { contract }\end{array}$ \\
\hline $\begin{array}{l}\text { Tender } \\
\text { management }\end{array}$ & $\begin{array}{l}\text { - Contract } \\
\text { administration } \\
\text { - Payment }\end{array}$ & $\begin{array}{l}\text { - Contract } \\
\text { management }\end{array}$ & $\begin{array}{l}\text { - Ensure ongoing } \\
\text { performance } \\
\text { achieve value for } \\
\text { money } \\
\text { - Manage contract } \\
\text { extension options, } \\
\text { termination, or } \\
\text { transition to new } \\
\text { contractor }\end{array}$ & $\begin{array}{l}\text { - Contract } \\
\text { management }\end{array}$ \\
\hline
\end{tabular}

\subsection{The Codes of Ethics for Tendering}

In Australia, a guide on contractors' ethics is spelled out and can be found in the Best Practice Guide for Tendering and Contract Management (Victorian Civil Construction Industry, 2008). The limitation in this guide is it does not contain any specific approach to prevent any unethical conduct and, therefore, it promotes the innovation of a delivery system to be introduced. In the United Kingdom, there is a Good Practice Contract Management Framework (National Audit Office, 2016), but the limitation is it only serves after the tender is concluded and not during tender evaluation. Bauld (2016) also found that the contractors' ethical issue for bid shopping arises in Canada. Similarly, the Malaysian construction industry outlined the Code of Ethics for Contractors (Construction Industry Development Board [CIDB], 2008) but the approach is not translated into a practical application in carrying out the tendering process.

\subsection{Falsification of Documents}

'Falsify' is defined by the Cambridge Dictionary as to change something, such as a document, in order to deceive people ("falsify," 2017a). The Longman Dictionary of Contemporary English Online defines 'falsify' as to change figures, records, etc. so that they 
contain false information ("falsify," 2017b). The Oxford Dictionary defines 'falsify' as alter (information, a document, or evidence) so as to mislead ("falsify," n.d.). The term 'falsification' is defined by the Oxford Dictionary as the action of falsifying information or a theory ("falsification," 2017). This article accepted all the definitions with an additional concept on the specific purpose of the contractors so as to increase their evaluation score or weightage, and consequently win a project award.

One of the unethical issues identified during the tender evaluation process is forgery of experience and qualification claims (Adnan, Hashim, Yusuwan, \& Ahmad 2012; Wan Ahmad \& Abd Ghadas, 2012). Even though the document forensics technology has developed rapidly to detect document falsification (Shang, Memon, \& Kong, 2014), the technology application is still poorly adopted in construction projects (Wang, Chong, Shou, Wang, \& Guo, 2014; Yih Chong, Balamuralithara, \& Choy Chong, 2011). The process and method to handle the issue are also varied from one agency to another. Therefore, whenever there is any doubtful or suspicious document encountered during the evaluation, then only an investigation is carried out. It causes extra work on the part of the evaluators and incurs time to get the feedback or authentication from the authorised person from the related agency. After that, if it is brought to the court, it incurs even more time, because the people involved usually have little tolerance to hold onto the matter until the end (Pamfil, 2013).

In the rapid growth of project development, the construction industry does not overlook the issues of integrity and ethics. Being incorporated in both CIMP and CITP, these issues have never failed to be addressed, and therefore regarded as a strong underlying factor in determining the success and quality of a project.

\subsection{The Integrated Registration of Contractors}

During the implementation of CIMP (20102015), the challenge observed was the initiative for the registration of contractors from two agencies, the Construction Industry Development Board (CIDB) and Pusat Khidmat Kontraktor (PKK) being integrated into only one agency, i.e., CIDB. Later in the plan, from 1st May 2014, PKK is known as Bahagian Pembangunan Kontraktor dan Usahawan (BPKU). The integration has been achieved in CIMP and it becomes the motivation for an integration of another operation process to be successful in support of CITP.

Currently, the number of contractors according to the registration grades in Selangor and Kuala Lumpur is as tabulated in Table 25. The contractor companies, like any other organisations, from G1 to G7, have the management and the operational teams for their day-to-day business.

Table 2: The population of the registered contractors by grade in Selangor and Kuala Lumpur

\begin{tabular}{llll}
\hline & Registration Grade & Population & Total \\
\hline Lower grades & G1 & 15,606 \\
\cline { 2 - 3 } & G2 & 5,667 & \\
\cline { 2 - 3 } & G3 & 3,503 & 7,244 \\
\cline { 2 - 3 } Higher grades & G4 & 4,731 & \\
& G5 & 1,705 & \\
& G6 & 2,822 & \\
\cline { 2 - 3 } & G7 & 372 & \\
\hline
\end{tabular}

Source: CIDB (2017)

\subsection{The Management and Operational Teams in Tendering}

In tendering process, the function of both the management and the operational teams are important. The management team is represented by the leaders and the operational team is represented by the evaluators. The leaders enable the mission while the evaluators enable the process. According to the enablers derived from the European Foundation for Quality Management (EFQM) as identified by Oladinrin and Ho (2015), the leadership enabler is regarded as the most important followed by the process enabler (Figure 2). In Malaysia, leadership is conducted at the 
management level and the process is conducted at the operational level where the evaluators are the key players. The two teams will have to work hand in hand. Communication is very important to get both teams (Figure 3) to support each other's needs. In a series of activities within a process, the enablers take turns to become a priority at different points of time. After the tender is being advertised and contractors submitted their documents, this is when the process enabler becomes a priority for screening by doing the filtration

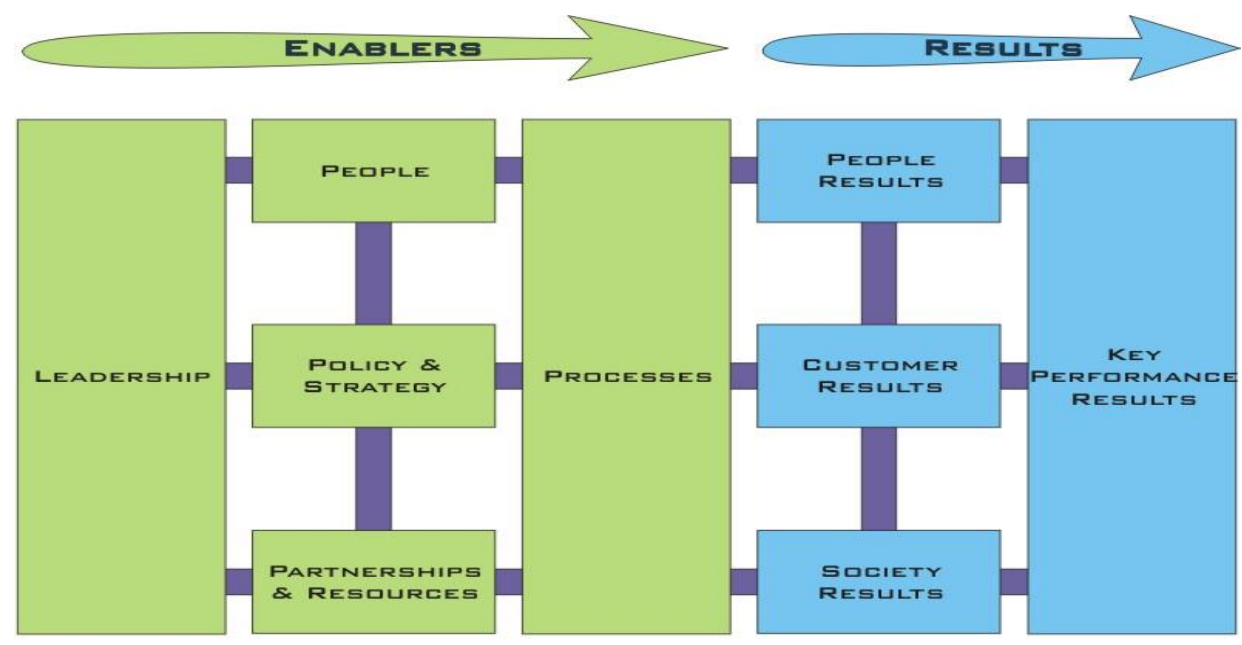

Figure 2: The EFQM Model

Source: The University of Warwick (2009)

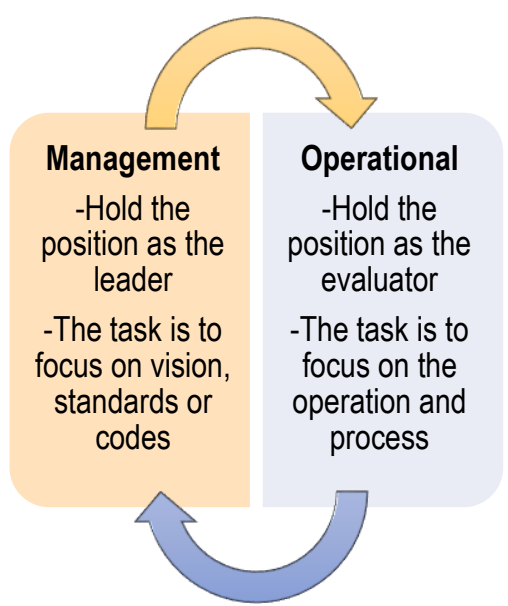

Figure 3: The Functions of the Management Team and the Operational Team

In tendering, the existing system and procedure are there, including the codes of conduct, for example, the Code of Ethics for Contractors by CIDB (2008). However, manipulation still takes place. That is why there is a need for translating the guides in the code with the combination of the procedure in the current tendering practice into a process for contractors' document submission 


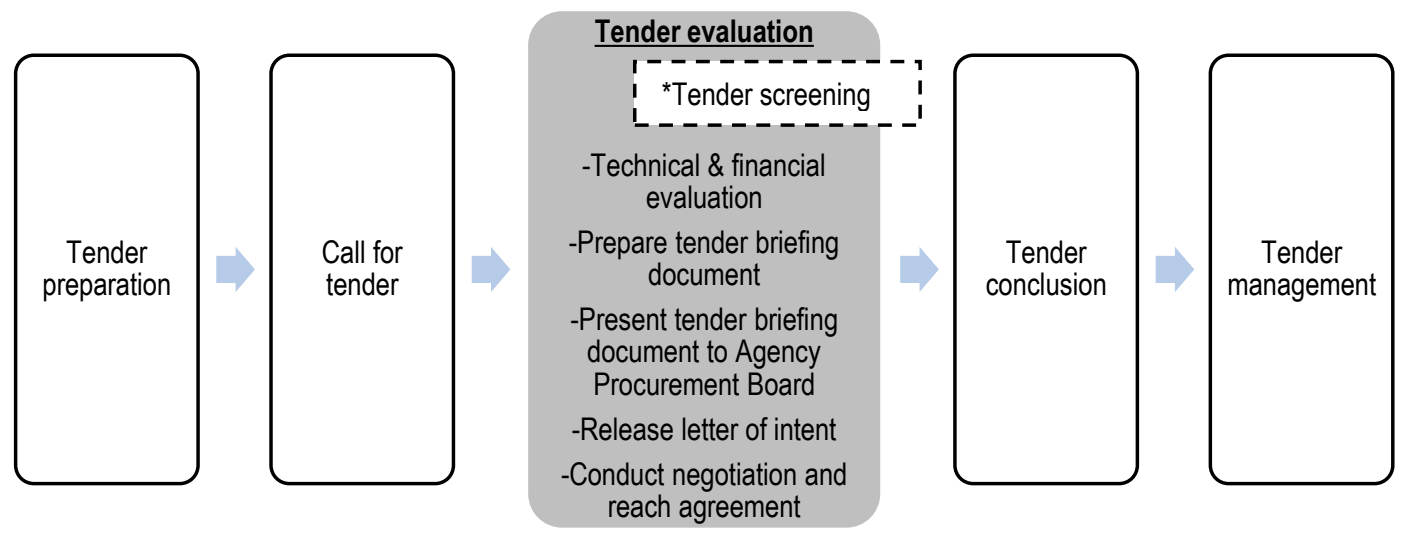

Figure 4: Tender Evaluation Activities in Tendering Process

Source: Ministry of Finance Malaysia (2016)

\subsection{Get it Right the From the Beginning}

Modern construction is moving towards long-term relationship. Being trustworthy and reliable are important to build a reputation in the industry. In reality, the relationship of the decision makers with the contractors can lead to bias and unethical conduct (Safa et al., 2015).

The total quality management principle, i.e., 'get it right the first time' is important for the contractor selection in tender evaluation (Wilkinson, Redman, Snape, \& Marchington, 1998). Getting to award the right contractor is vital to get an accurate and realistic result (Safa et al., 2015).

The contractors are required to uphold their highest integrity during the tendering exercise especially in relation to the submission of tender documentations. The validity of documents submitted are not being questioned if there is no suspicious evidence arise when being checked by the evaluators and it merely depends on the evaluators to detect any irregularities in the documents (Ibrahim, personal communication, November 18, 2016).

It is the job of the evaluators to examine whether those records are genuine, correct, and updated. This leads to working more than those stated in the job scope, without the conscience that the management or the leader imposes extra work and could cause demotivation (Lindebaum et al., 2017). Somehow, according to N. A. Shamsudin (personal communication, October 7, 2016), in practice, the evaluators do not have a direct authorisation to examine the authenticity of the records in the documents especially when it comes to financial statement and experience of work with private institutions. In relation to this issue, according to Armando and Ponta (2014), a question of the high-level authorisation requirement is of paramount importance.

Furthermore, another constraint of the evaluators is the tender validity period (Ibrahim, personal communication, November 18, 2016). Eventually, the forged documents could potentially get their way through the selection process and severely influence the recommendation for a successful tenderer. In relation to this, buildings took longer period to complete, finished buildings need major repair works, buildings face failure during occupation, and threaten the lives of the occupants are some of the common problems associated with the construction industry (Abdul-Rahman, AbdKarim, Mohd Danuri, Berawi, \& Yap, 2007; de Araújo, Alencar, \& de Miranda Mota, 2017; Jelodar, Yiu, \& Wilkinson, 2016; Liu, Wang, \& Wilkinson, 2016; Rosenfeld, 2014).

As shown in Figure 4, the tender evaluation process starts with the evaluation on the technical and financial capabilities, skipping the screening of the tender applications. Henceforth, this preliminary research was conducted in an attempt to explore the existence of ethics-related issues during tender evaluation and established the need for tender screening. This research is crucial in order to suggest the way forward to elevate the study in this area.

\section{RESEARCH METHODOLOGY}

The research methodology for this preliminary study was qualitative where 
telephone interviews were used as its data collection method.

\subsection{Telephone Interviews}

The telephone interviews were conducted because of the time taken to reach the participants is faster compared to face-toface interview. This method was chosen to save the travelling time.

\subsection{Data Organisation and Preparation}

The telephone interview process, as described by Burke (2001) and Burnard (1994), started with preparing the interview protocol according to the research questions. A structured interview was carried out for its easiness to categorise and analyse the data. The planning for the interview was to answer four questions. The first question is to find whether the participants, during their service in the current body, have ever encountered any occurrence of unethical conduct, especially falsification of documents by the contractors upon tender application submission. If the answer is 'yes', it is then followed by the second question on the frequency of the occurrences, and the third question, on the registration grade(s) of the contractor(s) involved. The fourth question is imposed either after the third question or after the first question being answered 'no'. The question is on the action(s) taken upon discovering the unethical conduct.

Interviews were scheduled with the relevant construction bodies to ensure important variables related to ethics in construction are not ignored and to capture the general practice in the handling of ethics-related issues in the construction industry. As suggested by Guest, Bunce, \& Johnson (2006) and Mohd Danuri, Mohd Ishan, Mustaffa, Abd-Karim, Mohamed \& Hanid (2016), the following criteria have been developed to guide the researcher in the selection of participants using purposive or judgement sampling approach:

i. The participant must be involved in contract administration practice, especially in tender evaluation exercise. According to Cheung and Suen (2002), participants who are very experienced, knowledgeable, possessed good skills, and hold senior managerial positions in the industry were essential, so that their views provide a good reflection in the field of research. To ensure homogeneity of the participants, the interview was directed to the persons holding the position to evaluate the contractors' tender submission, regardless of the names of their designation. Their work must be related to contract administration, tender evaluation, or managerial decision making.

ii. The localities of the chosen interviewees were in Kuala Lumpur and Selangor, to ensure a manageable amount of data, and due to time constraint of the grant issued, it would be difficult for this study to use the entire population in the quest of gaining knowledge about the tendering practice (Sekaran, 2006).

iii. Because contractors of lower grades (G1 to G4) are permissible to submit quotations only, after a deliberation on the similarity between a tender and a quotation in terms of the idea, concept, practice (including evaluation and selection processes) and purpose (to award the project to one competitive qualified bidder), the research widened the scope to include for quotations as well. The advantage was to have a wide spread of contractor grades for the research to focus on.

This research involved sixteen participants. The adequacy of this number is supported by Bertaux (1981), agreeing to fifteen responses, Smulkoski (2007), ten to fifteen, and Kuzel (1992), six to eight because of the homogeneity.

According to Maykut and Morehouse (1994), the data is adequate because there is no new information or new major concepts emerged in the last few interviews. The point is called saturation point (Strauss and Corbin, 1998) or redundancy (Lincoln and Guba, 1985). Patton (1990) agreed with the assertion that validity and richness of qualitative information should be according to the richness of information of the selection and analytical capabilities instead of the number of the participants. This is reinforced by Guest et al. (2006) proposing that saturation often occurs around twelve to fifteen participants in homogeneous groups. Homogeneous in this research refers to the same position of the interviewees where their job scope is to evaluate the contactors' bids upon tender application submission. 


\subsection{Data Collection and Management}

The length of interview was in the range of fifteen to forty minutes. Recording was done by taking notes during the interview. A foreseen challenge is to lose the data in between the conversation because the expression of the participants could only be anticipated as the real expression could not be seen. To encounter the challenge, the researcher repeated the answers for confirmation on the information given.

This approach tallied with Irvine, Drew, and Sainsbury (2013) where clarification is requested to check on the sufficiency and relevance of the responses during a telephone interview. Clarifications from both parties are necessary to avoid misunderstandings.

\subsection{Data Categorisation and Connection}

The raw data were typed according to the question numbers arranged in columns from left to right. The data needed to be understood to answer the research questions sufficiently. The data were read and re-read to find the sentences that could be linked with the research questions. This process is crucial to be done as soon as the call is over to avoid the researcher from forgetting any important information. Then, the important points were labelled and highlighted.

The first to the third questions were direct questions, but the fourth needed interpretation of the description. The highlighted points were interpreted and consequently categorised into a few groups. Later, they were given suitable themes.

\subsection{The Advantages and Disadvantages}

This method is found to be less bias compared to face-to-face, because in a faceto-face setting, people tend to be judgmental and carry their first impression throughout the interview. Any problem regarding reliance on first impressions does not exist because the interview was done by telephone, and not face-to-face.

The disadvantage of the telephone interview is the tendency to ignore conflicting information. This challenge was overcome by repeating the questions and answers to confirm the information, especially on the unusual or new information.
The interviewer had to speak up to indicate that they were still on the line. To maintain a natural response, avoiding over or under reaction was a challenge. To handle the situation, the interviewer needed to be focused and calm along the session.

Another challenge is when there is too much data to handle. What the interviewer did was to ask the interviewee to slow down and at any opportunity to interrupt, the interviewer repeated the data for confirmation to stall the time.

\section{ANALYSIS}

\subsection{Background Analysis}

Gathering the information took four months. Out of forty-three participants identified, (inclusive of local authorities and other agencies), sixteen participated, which represented over one third of participation rate. The number represented nine local authorities and seven agencies.

In disclosing information, the local authorities were open (Bonsón, Torres, Royo, \& Flores, 2012; Kavanaugh et al., 2012; Linders, 2012) compared to agencies. A number of agencies turned down the request for information, partly because of their interest and image (Spiekermann, Korunovska, \& Bauer, 2012) and partly because of their strict policy. The need to have an agreement was agreed upon because one of the research processes is to get the consent from the participants. Possibly, involuntary participants were avoided because the trust was not instilled from the beginning. The situation led to other theories related to the environment and political influence, which are not discussed in this paper. From this point forward, the discussion involved the interviews with these sixteen participants.

\subsection{Presence of Unethical Conduct of Contractors during Tender Submission}

From the total participation, seventy five percent of the participants agreed on having encountered unethical conduct by contractors during tender submissions. Out of the percentage, sixty seven percent were from the local authorities and thirty three percent were from the agencies. The responses stating not having encountered any unethical issues from the contractors, three quarter of the responses were from the 
agencies and another quarter were mentioned by the local authorities.

One of the local authorities admitted that she did not experience fraud in documents. A question was asked to find out whether there is a system that can prevent or avoid fraud. If there is one, it could be used as a benchmark for other local authorities to adopt. Surprisingly, the answer was that it trusted completely on the contractors' documents because all contractors must sign the required letter of undertaking. In the letter, it states that the contractors are bound to supply all the correct information in their applications. To highlight, the contractors may just sign to complete the forms among other compulsory submissions. As there is no system to benchmark, this move is considered risky to the local authority itself. In the researcher's opinion, the local authority should at least do some random checking on the submissions occasionally to see whether their practice on trust is still strong and accountable.

On the other hand, the reasons of those other three agencies for not experiencing such occurrence were due to a small number of tender calls in a year (less than ten), which do not require financial or bank statements unless specially requested by the management and deal with copied documents only.

The agencies also practised to check the contractors' information against MOF and Companies Commission of Malaysia (SSM) information for the scope of work, business nature registered by the contractors, and checking of registration status of the contractors via CIDB application. This checking is done manually by making calls and visits. This method establishes there is no system to curb fraud by contractors at the point of tender submission for evaluation.

\subsection{The Frequency of Document Falsification Occurrences}

The participants were asked on how many document falsification occurrences had they come across, say, in a hundred tender application submissions. Their answers had been recorded and grouped into low, moderate, high, and very high. The low group was noted for the falsification occurrence of one to three in a hundred tender application submissions. The moderate group was for four to six occurrences. The high group was for seven to nine occurrences. The very high group faced ten or more occurrences in a hundred tender application submissions.

The frequency of the document falsification occurrences encountered by the tender evaluators depends on a lot of factors; how many calls for tender are made, how big the amount of tender is, the tenders are called for which contractor categories (which grades), how influencing is the economy and competition during the time of year, how much allocation is there for projects (Delgado, Porter, \& Stern, 2010; Glaeser, Rosenthal, \& Strange 2010).

In light of these factors, not all participants who responded "yes" to the previous questions were able to give an answer or an estimate of the document falsification occurrence frequency. Only ten answers managed to be obtained, in which six of them were from the local authorities.

Half of the responses were recorded into the low group. Thirty percent of the responses came from the local authorities and twenty percent of the responses came from the agencies. The frequency of having encountered moderate number of cases was thirty percent, where ten percent of the responses came from the local authorities and twenty percent of the responses came from the agencies. However, the rest twenty percent of the responses made a significant gap, whereby it leaped over the high group straight to the very high group. The group was encountered only by the local authorities and none by the agencies. This could be related to the numerous amount of projects offered by the local authorities compared to the amount of projects offered by the agencies.

To curb from awarding these fraudulent contractors the projects, the evaluators need to put an extra effort to identify and discard their applications. However, it is unfair to put the burden of other people's bad behaviour onto those who have other important job and time scope to be fulfilled instead of carrying out an investigation, which is not what they are expected to do. They already have their deadlines to commit to, and the last thing they need is a distraction keeping them from their originally assigned tasks. Indeed, it is best if no contractors cheat at all. However, that is difficult to expect because the situation depends on the surrounding factors. Contractors are human, and human 
behaviours, even though hard to change, are not static, thus not dependable.

\subsection{The Document Falsification Occurrence According to the Contractor Registration Grade}

All contractors must register the grades and get the Registration of Contractor licences from CIDB. Other than the licence, for Government projects, Sijil Perolehan Kerja Kerajaan (SPKK) is required as an addition to the licence. SPKK is also issued by CIDB but this study concerned on the Registration of Contractor licences only. Therefore, the discussion of the grades addresses the CIDB grade classifications.

According to the interview, the inclination to submit the falsified documents fell on the categories of contractors of the lower grades, mostly involving the G1 contractors, at twenty-seven percent rate. The G2 and G3 contractors followed with twenty-three percent each. The G4 contractors were at nineteen percent. The total percentage for these lower grades was eighty two percent, a much substantial amount compared to the upper grades. The upper grades were less prone to the conduct where the G5 and G7 contractors were found at four percent each. No occurrence involved the G6 contractors.

This is fairly anticipated because the contractor companies of higher grades (G5 to G7) are likely to be listed in Bursa Malaysia, which make their profiles accessible by the public. They must maintain the good reputation to sustain in the board because their documents can be easily checked against their profiles.

\subsection{Actions Taken Upon Encountering Falsified Documents}

In cases where falsified documents were found, the most popular action taken by more than half of the local authorities and agencies was to immediately disqualify the application.

This practice instantly fails the application and it may extend into blacklisting the companies from entering the future bids.

Besides automatically disqualifying the tender application, a quarter of the participants brought the case to the internal board or committee where their discretion and advice were sought. This committee would decide whether to let the tender pass for evaluation, to disqualify the application, to blacklist, or to suspend the companies from entering the bid for coming project(s). Normally, the result was to blacklist and suspend the applicant.

Apart from an internal action, the case might also be brought forward to the external parties, for example to CIDB or MOF. Then, they would investigate the case and if the contractor was found guilty, the licence could be suspended or forfeited.

Nevertheless, a small number of participants stated that there was no action taken upon encountering the forged documents, and the contractors would still be in the running for the tender award.

\section{DISCUSSION}

This article highlighted the unethical issues during tender submission. Surprisingly, the findings showed that the falsification of documents by the tenderers was identified as early as at the tender submission stage. The industry is facing the issues yet there is little mechanism to tackle the problem. This issue could possibly reduce the competitiveness of a tender. The initiating phase in the Project Management Process Groups needs to be straightened to be correct. It is important because as agreed by Abdul-Rahman et al. (2007), it affects the next phases of the process and the overall project performance, on the triple constraints of time, quality, and cost of projects. Even though the guides and codes are spelled out by some countries, they remain only on paper. There must be a mechanism to put it into a working procedure for the contractors to comply.

The frequency of the unethical occurrences is correlated with the population of the registered contractors (Table 1) according to their grades. The higher the number of contractors in a registration group, the higher the occurrence of unethical conduct found during tender submission. It shows high competition influence the tendency of the contractors to become unethical. Because the number of contractors in the lower registration grades is large, it makes the competition tough, hence, the unethical conduct.

Somehow, as illustrated in Figure 3, the order of the leader in the management team, some of the companies do not require bank statements to be stamped by the financial 
institutions, because it will prolong the duration to evaluate the tender. It is also almost impossible to make the evaluators do the checking with the financial institutions on the supporting documents for each and every tender submitted because it is tedious and time consuming.

Furthermore, the huge concern here is time. The evaluation phase will elongate and the burden falls onto the person in charge, i.e., the evaluator. For every project, time is of the essence and it may drag other constraints too.

Most of the local authorities and agencies in the industry do not have a way to tackle the issue at the point of tender submissions, hence, the dependence by the management team on the operational team to filter the fraudulent contractors. The role of the leaders in the management is important to the evaluators in the operational team, similarly found in the research by Oladinrin and Ho (2015). Ozorhon, Abbott, and Aouad (2014) stated that innovation adoption is hard because of the nature of the parties in construction that is resistance to change. They then supported that the leaders should take the role to eliminate the barrier. The support to honour and uphold the procedure depends highly on the leaders.

Because some of the participants could not remember or even estimate the number of cases they had encountered, it is suggested for the companies to practise the record keeping as concurred by Basu, Bag, Das, and Razario (2017), at least for their internal reference. It is suggested for another mechanism to be inserted in the middle of the EFQM Model (Figure 2) for the management team to assist the operational team (Figure 3) with regards to the tendering procedure.

\section{CONCLUSION}

The establishment of the findings of the results in this research will serve as a preliminary study for further research of ethics in construction industry, particularly in relation to tender evaluation processes.

The information technology offers wide and tremendous benefits to many sectors (Naoum \& Egbu, 2015; Safa et al., 2015). With various frauds detecting software available, falsified documents could be detected (Newman, 2013; Wager, 2013). The integration of the appropriate software customised to the architecture, engineering and construction (AEC) industries and the competitive intelligence applications, at the right time, may offer a further standardisation for tender evaluation processes and enable its industry-wide acceptance and implementation.

The construction industry should make use of the competitive intelligence and the emerging digital tools in the AEC industries throughout the developing and developed countries (Rosli, Razak, \& Younus, 2016) to improve a bidding strategy and evaluation. An improvement mechanism should be carried out for the benefit of the construction industry. Future research should focus on developing a framework of an integrated system that supports the tender evaluation process with the information workflow among various sources. To start with, the system may look into the mistake-proofing mechanism at the beginning of the process. The customisation of the mechanism should take the inspiration from the poka-yoke inadvertent error prevention approach.

The early detection and prevention mechanism to block the fraudulent contractors from being able to apply for tender will directly support the evaluators in the tender evaluation process, and indirectly strengthen the image of the construction industry.

\section{ACKNOWLEDGEMENT}

This paper represents part of the findings from a university research grant by the Centre of Research Grant Management, University of Malaya (Project Number: BKS040-2017). The research work was also supported by the Ministry of Higher Education (Malaysia) and Universiti Malaysia Pahang.

\section{REFERENCES}

Abdul-Rahman, H., Abd-Karim, S. B., Mohd Danuri, M. S., Berawi, M. A., \& Yap, X. W. (2007, September). Does professional ethic affects construction quality? Paper presented at the Quantity Surveying International Conference, Kuala Lumpur, Malaysia. Retrieved from https://www.researchgate.net/publication /264041697_Does_Professional_Ethic_A ffects_Construction_Quality

Adnan, H., Hashim, N., Yusuwan, N. M., \& Ahmad, N. (2012). Ethical Issues in the Construction Industry: Contractor's Perspective. Procedia - Social and 
Behavioral Sciences, 35, 719-727. doi:10.1016/j.sbspro.2012.02.142

Armando, A., \& Ponta, S. E. (2014). Model checking authorization requirements in business processes. Computers \& Security, 40, 1-22. doi:10.1016/j.cose.2013.10.002.

Basu, D., Bag, S. C., Das, A., \& Razario, J. D. (2017). The importance of paper records and their preservation period in a Central Sterile Supply Department: An experience from a oncology center in eastern India. Journal of Infection and Public Health, 10(5), 685-687. doi:10.1016/j.jiph.2016.10.004

Bauld, S. (2016, June 8). Procurement Perspectives: Tender issues, limitations and benefits explored. Daily Commercial News. $\quad$ Retrieved from http://journalofcommerce.com/Governm ent/News/2016/6/ProcurementPerspectives-Tender-issues-limitationsand-benefits-explored-1016547W/

Bertaux, D. (1981). From the life-history approach to the transformation of sociological practice. In Daniel Bertaux (Ed.), Biography and society: The life history approach in the social sciences (pp.29-45). London: SAGE.

Bonsón, E., Torres, L., Royo, S., \& Flores, F. (2012). Local e-government 2.0: Social media and corporate transparency in municipalities. Government Information Quarterly, 29(2), 123-132. doi:10.1016/j.giq.2011.10.001

Burke, L., \& Miller, M. (2001). Phone Interviewing as a means of data collection: Lessons learned and practical recommendations. Forum Qualitative Sozialforschung / Forum: Qualitative Social Research, 2(2). doi:10.17169/fqs$\underline{2.2 .959}$

Burnard, P. (1994). The telephone interview as a data collection method. Nurse Education Today, 14(1), 67-72. doi:0.1016/0260-6917(94)90060-4

Cheung, S.-O., \& Suen, H. C. H. (2002). A multi-attribute utility model for dispute resolution strategy selection. Construction Management and Economics, 20(7), 557-568. Doi:10.1080/01446190210157568

CMS Law-Now (2015). Guide to the EU public procurement rules in the $U K$. Retrieved from http://www.cmslawnow.com/publications/2015/05/6may-2015-guide-to-the-eu-publicprocurement-rules-in-the-uk

Construction Industry Development Berhad Malaysia. (2008). Code of ethics for contractors - Construction industry. Kuala Lumpur: CIDB.

Construction Industry Development Berhad Malaysia. (2017). Statistik pendaftaran kontraktor PPK, SPKK \& STB Julai 2017. Kuala Lumpur: CIDB.

Construction Group. (2016). Project Delivery Methods: Design and Construct $(D \& C)$. Retrieved from http://constructionsgroup.com.au/projectdelivery-methods.php

Controller and Auditor-General (2008). Procurement guidance for public entities. $\quad$ Retrieved from https://www.oag.govt.nz/2008/procurem ent-guide/docs/procurement-guide.pdf

de Araújo, M. C. B., Alencar, L. H., \& de Miranda Mota, C. M. (2017). Project procurement management: A structured literature review. International Journal of Project Management, 35(3), 353-377. doi:10.1016/j.ijproman.2017.01.008

Delgado, M., Porter, M. E., \& Stern, S. (2010). Clusters and entrepreneurship. Journal of Economic Geography, 10(4), 495-518. doi:10.1093/jeg/lbq010

Department of Finance and Deregulation. (2013). Selling to the Australian Government. Retrieved from https://www.finance.gov.au/sites/default/ files/A_guide_for_business.pdf? $\mathrm{v}=1$

Department of Finance and Deregulation. (2013). 2013/02 - Australian Government Grants: Briefing and Reporting. Retrieved from https://www.finance.gov.au/archive/archi ve-of-publications/financecirculars/2013/02/

Evans \& Peck Pty Limited \& Australian Constructors Association. (2006). Guidelines for tendering. Retrieved from http://www.constructors.com.au/wpcontent/uploads/2006/08/Guidelines-forTendering-11-August-20061.pdf

Falsify. (n.d.). In ldoceonline.com. Retrieved October 25, 2017, from https://www.ldoceonline.com/dictionary/ falsify

Falsification. (2017). In oxforddictionaries.com. Retrieved from https://en.oxforddictionaries.com/definiti on/falsification

Falsify. (2017a). In dictionary.cambridge.org. Retrieved from https://dictionary.cambridge.org/dictiona ry/english/falsify

Falsify. (2017b). In oxforddictionaries.com. Retrieved from https://en.oxforddictionaries.com/definiti 
on/falsify

Glaeser, E. L., Rosenthal, S. S., \& Strange, W. C. (2010). Urban economics and entrepreneurship. Journal of Urban Economics, 67(1), 1-14. doi:10.1016/j.jue.2009.10.005

Guest, G., Bunce, A., \& Johnson, L. (2006). How many interviews are enough? An Experiment with Data Saturation and Variability. Field Methods, 18(1), 59-82. doi:10.1177/1525822X05279903

Irvine, A, Drew, P, Sainsbury, R. (2013). 'Am I not answering your questions properly?' Clarification, adequacy and responsiveness in semi-structured telephone and face-to-face interviews. Qualitative Research, 13(1), 87-106. doi:10.1177/1468794112439086

Jaafar, M., \& Nuruddin, A. R. (2012). The development of public and private construction procurement systems in the Malaysian construction industry. Journal of Design and Built Environment, 11, 1-11. Retrieved from http://umijms.um.edu.my/filebank/publis hed_article/4220/The\%20development $\%$ 20of\%20public \%20and\%20private\%20c onstruction $\% 20$ procurement $\% 20$ systems $\% 20$ in $\% 20$ the $\% 20$ Malaysian\%20constru ction\%20industry.pdf

Jabatan Kerja Raya Malaysia. (2016). Laman Web Rasmi Cawangan Kontrak dan Ukur Bahan. Retrieved from https://www.jkr.gov.my/ckub/

Jelodar, M. B., Yiu, T. W., \& Wilkinson, S. (2016). A conceptualisation of relationship quality in construction procurement. International Journal of Project Management, 34(6), 997-1011. doi:10.1016/j.ijproman.2016.03.005

Kavanaugh, A. L., Fox, E. A., Sheetz, S. D., Yang, S., Li, L. T., Shoemaker, D. J., Xie, L. (2012). Social media use by government: From the routine to the critical. Government Information Quarterly, 29(4), 480-491. doi:10.1016/j.giq.2012.06.002

Kuzel, A. J. (1992). Sampling in qualitative inquiry. In B. F. Crabtree, \& W. L. Miller (Eds.), Doing qualitative research (Vol. 3.) Newbury Park, CA: SAGE.

Lincoln, Y. S., \& Guba, E. G. (1985). Naturalistic inquiry. Newbury Park, CA: SAGE

Lindebaum, D., Geddes, D., \& Gabriel, Y. (2017). Moral emotions and ethics in organisations: Introduction to the special issue. Journal of Business Ethics, 141(4), 645-656. doi:10.1007/s10551-016-3201$\mathrm{Z}$
Linders, D. (2012). From e-government to we-government: Defining a typology for citizen coproduction in the age of social media in the age of social media. Government Information Quarterly, 29(4), 446-454. doi:10.1016/j.giq.2012.06.003

Ling, F. Y. Y., Leow, X. X., \& Lee, K. C. (2016). Strategies for Attracting More Construction-Trained Graduates to Take Professional Jobs in the Construction Industry. Journal of Professional Issues in Engineering Education and Practice, 142(1), $1-11$. doi:10.1061/(ASCE)EI.19435541.0000256

Liu, T., Wang, Y., \& Wilkinson, S. (2016). Identifying critical factors affecting the effectiveness and efficiency of tendering processes in Public-Private Partnerships (PPPs): A comparative analysis of Australia and China. International Journal of Project Management, 34(4), 701-716. doi:10.1016/j.ijproman.2016.01.004

Maykut, P. S., \& RMorehouse, R. E. (1994). Beginning qualitative research: A philosophical and practical guide. London: The Falmer Press.

Ministry of Finance Malaysia. (2015). Kaedah Perolehan Kerajaan. Retrieved from http://1pp.treasury.gov.my/subtopik/fail/159/muat-turun

Ministry of Finance Malaysia. (2016). MyProcurement. Retrieved from http://myprocurement.treasury.gov.my/

Mohd Danuri, M.S., Mohd Ishan, Z., Mustaffa, N.E., Abd-Karim, S.B., Mohamed, O. and Hanid, M. (2016). Dispute Avoidance Procedure: Formulating a Workable Legal System in the Malaysian Construction Industry. Journal of Design and Built Environment. June 16(1)

National Audit Office. (2016). Good practice contract management framework. Retrieved from https://www.nao.org.uk/wpcontent/uploads/2016/12/Good_practice_ contract_management_framework.pdf

Naoum, S., \& Egbu, C. (2015). Critical review of procurement method research in construction journals. Procedia Economics and Finance, 21, 6-13. doi:10.1016/S2212-5671(15)00144-6

Newman, A. (2013). The art of detecting data and image manipulation. Retrieved from https://www.elsevier.com/editorsupdate/story/publishing-ethics/the-art-ofdetecting-data-and-image-manipulation 
Nordin, R. M., Takim, R., \& Nawawi, A. H. (2013). Behavioural factors of corruption in the construction industry. Procedia Social and Behavioral Sciences, 105, 64-74. doi:10.1016/j.sbspro.2013.11.008

Oladinrin, O. T., \& Ho, C. M. F. (2015). Critical enablers for codes of ethics implementation in construction organizations. Journal of Management in Engineering, 32(1), 1-10. doi:10.1061/(ASCE)ME.19435479.0000385.

Ozorhon, B., Abbott, C., \& Aouad, G. (2013). Integration and leadership as enablers of innovation in construction: Case study. Journal of Management in Engineering, 30(2), 256-263.

Pamfil, M. L. (2013). The admission of guilt and its consequences in the Romanian legislation. Procedia - Social and Behavioral Sciences, 92, 673-677. doi:10.1016/j.sbspro.2013.08.737

Park, J.-G., \& Lee, J. (2014). Knowledge sharing in information systems development projects: Explicating the role of dependence and trust. International Journal of Project Management, 32(1), 153-165. doi:10.1016/j.ijproman.2013.02.004

Patton, M.Q. (1990) Qualitative Evaluation and Research Methods ( $2^{\text {nd }}$ ed.). Newbury Park, CA: Sage Publications.

Project Management Institute. (2013). Project Management Institute 2013 annual report. Retrieved from http://www.pmi.org/-

/media/pmi/documents/public/pdf/about/ annual-reports/pmi-annual-reportconsolidated-financials-2013.pdf

Raja, S. (2014). A crippling sin: An exploration of 'Greed' in global news magazine discourse. Global Media Journal. Retrieved from http://www.globalmediajournal.com/ope $\mathrm{n}$-access/a-crippling-sin-an-explorationof-greed-in-global-news-magazinediscourse.pdf

Rosenfeld, Y. (2014). Root-cause analysis of construction-cost overruns. Journal of Construction Engineering and Management, $\quad$ 140(1), 51-60. doi:10.1061/(ASCE)CO.19437862.0000789

Rosli, M. F., Razak, A. S. A., \& Younus, M. A. (2016). To BIM or not to BIM: A pilot study on University of Malaya's architectural students'software preference. Journal of Design and Built Environment, 16(1), 13-26.

Safa, M., Shahi, A., Haas, C. T., Fiander-
McCann, D., Safa, M., Hipel, K., \& MacGillivray, S. (2015). Competitive intelligence (CI) for evaluation of construction contractors. Automation in Construction, 59, 149-157. doi:10.1016/j.autcon.2015.02.009

Scalza, A. (2008). Ethics in the construction industry teaching students ethics in this 21 st century global market. Paper presented at the Proceedings of the 2008 Mid-Atlantic Conference of the American Society for Engineering Education. Retrieved from https://web.stevens.edu/asee/fileadmin/as ee/pdf/Scalza_-_final.pdf

Sekaran, U. (2006). Research Methods for Business - A Skill Building Approach $\left(4^{\text {th }}\right.$ ed.). India: John Wiley \& Sons, Inc.

Shang, S., Memon, N., \& Kong, X. (2014). Detecting documents forged by printing and copying. EURASIP Journal on Advances in Signal Processing, 2014(1), 140. doi:10.1186/1687-6180-2014-2140

Skulmoski, G. J., Hartman, F. T., \& Krahn, J. (2007). The Delphi method for graduate research. Journal of Information Technology Education, 6, 31-52. doi:10.28945/199

Spiekermann, S., Korunovska, J., \& Bauer, C. (2012). Psychology of ownership and asset defense: why people value their personal information beyond privacy. In Thirty Third International Conference on Information Systems (pp. 1-20). Orlando.

Strauss, A., \& Corbin, J. (1998). Basics of qualitative research: techniques and procedures for developing grounded theory ( $2^{\text {nd }}$ ed.). Thousand Oaks, CA: Sage Publications.

The University of Warwick. (2009, Mar 17). The EFQM model. Retrieved from https://warwick.ac.uk/fac/sci/wmg/ftmsc/ courses/mbe-home/modules/efqm/

Wager, E. (2013). High-tech approaches to high-tech fraud. Retrieved from https://www.elsevier.com/connect/hightech-approaches-to-high-tech-fraud

Wan Ahmad, W. I., \& Abd Ghadas, Z. A. (2012). Code of ethics for the contractors as a mechanism for the self-regulation in Malaysia: An appraisal. In C. O. Egbu, L. Ruddock, P. Chynoweth, M. Sutrisna (Eds.), COBRA 2011: Proceedings of Royal Institution of Chartered Surveyors (RICS) Construction and Property (pp. 148-158). Retrieved from https://www.irbnet.de/daten/iconda/CIB_ DC24507.pdf

Wang, J., Chong, H. Y., Shou, W., Wang, X., \& Guo, J. (2014, September). BIM- 
Enabled Design Collaboration for Complex Building. In Y. Luo (Ed.), Cooperative Design, Visualization, and Engineering. CDVE 2014. Lecture Notes in Computer Science, Vol. 8683 (pp. 238-244). Springer, Cham. doi:10.1007/978-3-319-10831-5_35

Wilkinson, A., Redman, T., Snape, E., \& Marchington, M. (1998). Managing with Total Quality Management: Theory and Practice. Hampshire and London: Macmillan Press Ltd.

Yahya, R. (2016, October 17). Gantung lesen kontraktor cuai. Utusan Online, pp. 1-2. Retrieved from http://www.utusan.com.my/berita/wilaya h/kl-putrajaya/gantung-lesen-kontraktorcuai-1.395808

Yih Chong, H., Balamuralithara, B., \& Choy Chong, S. (2011). Construction contract administration in Malaysia using DFD: a conceptual model. Industrial Management \& Data Systems, 111(9), 1449-1464.

Victorian Civil Construction Industry (2008). Best practice guide for tendering and contract management. Retrieved from

https://www.google.com/url?sa=t\&rct=i $\& \mathrm{q}=\&$ esrc $=$ s \& source $=$ web $\& \mathrm{~cd}=1 \& \mathrm{cad}=\mathrm{r}$ ja\&uact $=8 \&$ ved $=0$ ahUKEwia8 -

XWgKLXAhWBs48KHTUzAuwQFggo

MAA\&url=http\%3A\%2F\%2Fwww.welli ngton.vic.gov.au\%2Ffiles\%2Fa708f74e1c2f-4365-8b53-

a1d300a96e05\%2FVCCI-Best-PracticeGuide-for-Tendering-and-ContractManagement.pdf\&usg=AOvVaw0wIFaz D84YXAh4aS4mt8Sw 
